\title{
Emission Data and Costs for Environmental Measures During Laser Joining of Metals
}

\author{
Jürgen WALTER, Michael HUSTEDT, Christian HENNIGS, Johannes STEIN, Stephan BARCIKOWSKI \\ Laser Zentrum Hannover e.V. (LZH), Hollerithallee 8, 30419 Hannover, Germany \\ E-mail: j.walter@lzh.de
}

\begin{abstract}
Laser welding and soldering are important joining processes in the automotive industry. Typical examples are the production of the car body of the VW Golf or the automatic gearbox of the Mercedes-Benz A-Class. Furthermore, there is a general trend to increase the use of lightweight materials (e.g. $\mathrm{Mg}, \mathrm{Al}$, alloys), and to combine different metallic materials to produce complex components (e.g. in tailored blanks). In order to ensure good practices with regard to occupational health and safety as well as environmental issues, laser joining processes have to be analyzed in detail. Avoiding and controlling emission products caused by laser processing of metals or metal composites is an important task in this context. Typically, costs for environmental measures represent a significant percentage of the total manufacturing costs related to a laser process.

In this work, emission measurements of several laser welding and soldering processes for metal sheets from steel and brass are reported. Different steel grades and surface treatments of the metal sheets have been taken into account: pure, zinc-coated, PTFE-coated, oiled, cold cleaner residues. The hazardous potential of these processes has been assessed by means of analyzing the specific emissions with respect to the relevant threshold limit values (TLVs). Based on the experimental results, the processes have been classified according to measures which are required by environmental legislation. Finally, a cost calculation for measures related to emission capturing is presented. It has been shown that these environmental measures are manageable for all industrial laser processes regarded here, and the costs for these measures remain acceptable, i.e. in many cases below $8 \%$ of the total processing costs. The results are made permanently available in an interactive internet database. Using this database, the planning of appropriate exhaust systems for laser welding and soldering is facilitated significantly.

DOI: $10.2961 / \mathrm{j} \operatorname{lmn} .2011 .02 .0008$
\end{abstract}

Keywords: environmental protection, laser joining, metals, characteristic values of emissions, costs

\section{Introduction}

During the last ten years, the global market for laser systems in the field of macro processing, including laser joining applications, has grown substantially [1]. In the same period, the global competition in the field of metal processing has increased steadily. Small and medium-sized enterprises (SMEs), such as laser job shops and automotive suppliers [2,3], face a high cost pressure. Regarding highly automated laser joining processes, the potential for further reduction of production costs is low. However, the indirect costs attributed to the disposal of process by-products still exhibit possibilities of reduction.

Usually, a filtering system has to be integrated into the process chain to exhaust both gases and dusts emitted from the process zone. In order to minimize the corresponding investment and operating costs, the exhaust system shall be specifically planned for each application in order to avoid oversizing [4-6]. A cost-optimized planning is only possible if the specific emissions are known for each kind of joining process. Data bases of process emissions may in principle be used to predict the emissions for an industrial process. Unfortunately, existing data bases are out-of-date, because they were generated more than 10 years ago, and laser machines and processes have changed significantly since that time $[7,8]$. These data bases may help to ascertain the emission products in a qualitative way, which still has to be confirmed. However, it cannot be expected that these databases reflect quantitative values at an accuracy which is required for planning cost-optimized exhaust systems.

Besides the developments in laser technology, new trends in semi-finished products have come up, such as multi-metal material mixes. The old databases do not allow the prediction of emissions for laser joining processes of different metallic materials. Due to the lack of up-to-date data, optimization of fume capturing and exhaust technology requires extended experimental investigations to quantify the gaseous and particulate emissions for each specific process, which is usually a very time-consuming procedure.

In this work, the emissions of several laser welding and soldering processes for metal sheets (mostly steel) have been investigated. Different steel grades and surface treatments of the metal sheets have been taken into account: pure, zinc-coated, PTFE-coated, oiled, cleaner residues. The hazardous potential of these processes has been assessed by means of analyzing the specific emissions with respect to the relevant threshold limit values (TLVs). The processes have been classified according to measures which are required by German environmental legislation ("TA Luft" [9]). Finally, the results of a cost calculation for measures related to emission capturing are presented as fraction of the total production costs. The results are integrated into an interactive internet database [10]. Using this 
database, the planning and selection of appropriate exhaust systems for laser welding and soldering applications can be facilitated significantly, at the same time meeting the requirements of both SMEs and automotive suppliers. Experimental investigations in order to optimize the exhaust system for a specific laser application can be reduced.

\section{Experimental}

Twelve specific joining processes have been investigated, including eleven welding processes and one soldering process. The welding processes can be further classified into six deep penetration welding and five heat conduction welding processes. Different steel grades have been investigated, including typical industrial surface treatment conditions (pure, oiled, cleaned with residues of cold cleaner, PTFE-coated, zinc-coated, see Table 1).

Emission measurements were performed for different laser process environments (gantry systems, robots, remote systems). In this work, only those emissions have been regarded for the deduction of waste-gas cleaning measures and the calculation of the corresponding costs, which were captured by the exhaust system. Emissions which were not captured and thus released into the working area have not been taken into account, although they are highly important regarding occupational health. In most working stations, it was ensured by means of analysing a defined aerosol generation that the major part of the emissions $(>85 \%)$ was captured by the exhaust system at the process. In one work station, the capturing efficiency was lowered significantly when an additional exhaust system for the complete laser cabin was turned on. Depending on the local process environment, specific constructional measures have been taken by the manufacturer to ensure high capturing performance. In addition, it was confirmed by measurements in the working area (distance to the process: $3 \mathrm{~m}$ ) that concentrations of hazardous compounds were far below the values required by occupational health regulations (TRGS 900 [11]).

Emission rates of specific components have been determined from the mass flow in the exhaust system. For this purpose, a special sampling tube is included in the exhaust pipe system (see Fig. 1), from which partial volume flows are taken off and directed to on-line sensors and discontinuous sampling filters. The detailed experimental set-up for sampling and measurement of particulate and gaseous emissions from laser processes is described elsewhere [12]. Sampling was performed corresponding to the German guideline VDI 2066 [13] at isokinetic air flow conditions [14]. Depending on the location of the laser process, a stationary (on-site LZH) or a mobile (on-site industry) sampling system was used. Each experiment was repeated three times in order to account for statistical deviations.

Pressure, temperature and humidity were measured online in order to allow for relating the emission values to a normalized volume. Both gaseous and particulate emissions in the exhaust air were investigated.

\subsection{Gaseous emissions}

Carbon monoxide was measured online for all joining combinations. Furthermore, the total gaseous hydrocarbon concentration was measured on-line using a flame ionization detector (FID) in case of metals having an organic coating. For a more specific analysis of organic compounds, small parts of the gas stream were directed through sampling filters with appropriate adsorption materials. These samples were analyzed with regard to non-polar and polar hydrocarbons using GC-MS as well as aldehydes and ketones using HPLC. The GC-MS samples were analyzed quantitatively with respect to the main components benzene, toluene, ethylbenzene and xylene. In addition, the GC-MS spectrum was analyzed qualitatively with regard to other components (assignment of retention time peaks).

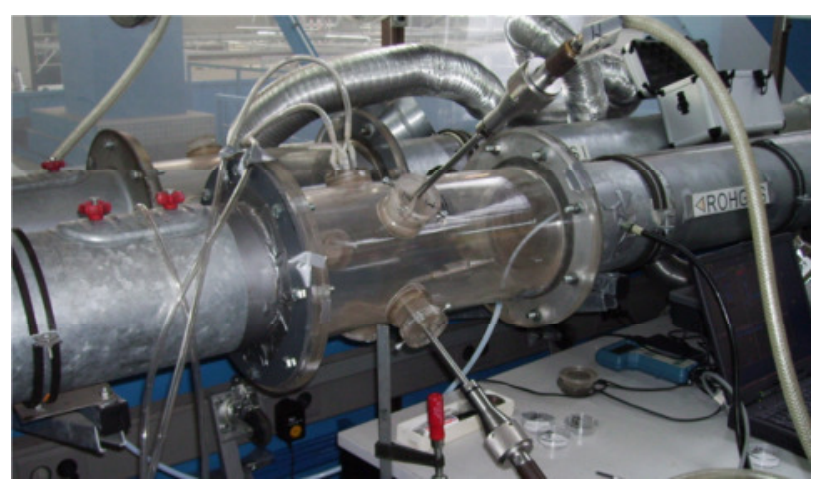

Fig. 1 Metering box (including probes), tube diameter $100 \mathrm{~mm}$.

\subsection{Particulate emissions}

Size distributions of particulate emissions were measured online using an electrical online 12-stage low pressure cascade-impactor (ELPI) of Dekati Inc. (Tampere, Finland) [15]. Amount and chemical nature of solid and liquid particulate emissions (aerosols) were determined in a discontinuous way. Aerosols were collected and concentrated on a sampling filter. The total amount of aerosol was determined gravimetrically, including inorganic and organic components.

The chemical composition of particulate emissions with respect to inorganic elements was determined using SEMEDX (energy-dispersive X-ray spectroscopy of a scanning electron microscope). SEM-EDX provides the relative portion of each inorganic element with respect to the other elements within the sample, however, it does not provide an absolute value with respect to the concentration in the air stream. Thus, quantitative chemical analysis was performed only, if a hazardous inorganic compound was found in the SEM-EDX analysis (e.g. $\mathrm{Cr}$ in case of stainless steel). Furthermore, quantitative chemical analyses were performed for low volatile hazardous organic compounds (regarding 16 polycyclic aromatic hydrocarbons, $\mathrm{PAH}$, according to the US Environmental Protection Agency, EPA).

Knowing i) the air volume pumped through the exhaust system (which was different for different processes), ii) the fraction of gas directed to the sampling filter or online measurement system, and iii) the concentration of the respective emission component, characteristic emission values have been calculated such as emitted mass per unit time $[\mathrm{mg} / \mathrm{s}]$. Alternatively, the amount of emission could be related to the joining length $[\mathrm{mg} / \mathrm{m}]$ or to the number of pieces produced.

The characteristic emission values have been assessed with respect to threshold limit values (TLVs) listed in [9]. For each joining process, the extent of air cleaning measures has been evaluated, and the processes have been classified into four categories. Finally, the characteristic 
Table 1 Process parameters for the different metallic laser joining combinations regarded in this work.

\begin{tabular}{|c|c|c|c|c|c|c|c|c|c|c|}
\hline no. & materials & $\begin{array}{l}\text { thickness } \\
\text { [mm] }\end{array}$ & $\begin{array}{l}\text { coating / } \\
\text { treatment }\end{array}$ & $\begin{array}{l}\text { laser type / } \\
\text { output power }\end{array}$ & geometry & $\begin{array}{l}\text { focal } \\
\text { length } \\
{[\mathrm{mm}]}\end{array}$ & $\begin{array}{c}\text { protective } \\
\text { gas }\end{array}$ & $\begin{array}{c}\text { feed } \\
\text { rate } \\
{[\mathrm{m} / \mathrm{min}]}\end{array}$ & $\begin{array}{c}\text { spot size / } \\
\text { weld seam } \\
{[\mathrm{mm}]}\end{array}$ & $\begin{array}{l}\text { joining } \\
\text { process }\end{array}$ \\
\hline 1 & $\begin{array}{l}\text { a) DC06 ZE 50/50 } \\
\text { b) DC06 ZE 50/50 }\end{array}$ & $\begin{array}{l}\text { a) } 0.75 \\
\text { b) } 0.75\end{array}$ & $\begin{array}{c}\mathrm{a}+\mathrm{b}: \\
\text { zinc-coated }\end{array}$ & $\begin{array}{c}\text { Nd:YAG } \\
2,700 \mathrm{~W}(\mathrm{cw})\end{array}$ & butt joint & 165 & without & 2.3 & $3.2-3.4$ & soldering \\
\hline 2 & $\begin{array}{l}\text { a) DC 05/06 } \\
\text { b) HLAD340 }\end{array}$ & $\begin{array}{l}\text { a) } 0.7 \\
\text { b) } 1.5\end{array}$ & $\begin{array}{c}\mathrm{a}+\mathrm{b}: \\
\text { zinc-coated }\end{array}$ & \multirow{4}{*}{$\begin{array}{c}\text { Nd:YAG } \\
\text { 4,000 W (cw) }\end{array}$} & \multirow{4}{*}{ lap joint } & \multirow{4}{*}{200} & \multirow{4}{*}{ cross jet } & 3.6 & \multirow{4}{*}{$1.5-2.0$} & \multirow{4}{*}{$\begin{array}{l}\text { heat cond. } \\
\text { welding }\end{array}$} \\
\hline 3 & $\begin{array}{c}\text { a) HLAD340 } \\
\text { b) HLAD380 (Z } 100 \mathrm{MB})\end{array}$ & $\begin{array}{l}\text { a) } 1.5 \\
\text { b) } 2.5\end{array}$ & $\begin{array}{l}\mathrm{a}+\mathrm{b}: \text { zinc- } \\
\text { coated }\end{array}$ & & & & & 1.8 & & \\
\hline 4 & $\begin{array}{l}\text { a) DC06 } \\
\text { b) HLAD340 } \\
\text { c) HLAD340 }\end{array}$ & $\begin{array}{l}\text { a) } 0.7 \\
\text { b) } 1.5 \\
\text { c) } 1.5 \\
\end{array}$ & $\begin{array}{c}\mathrm{a}+\mathrm{b}+\mathrm{c}: \\
\mathrm{zinc}-\mathrm{coated}\end{array}$ & & & & & 1.9 & & \\
\hline 5 & $\begin{array}{l}\text { a) DC06 } \\
\text { b) Usibor } \\
\text { c) HLAD340 }\end{array}$ & $\begin{array}{l}\text { a) } 0.7 \\
\text { b) } 2.0 \\
\text { c) } 1.5 \\
\end{array}$ & $\begin{array}{c}a+c: \\
\text { zinc-coated }\end{array}$ & & & & & 1.6 & & \\
\hline 6 & $\begin{array}{l}\text { a) stainless steel } 1.4404 \\
\text { b) stainless steel } 1.4404\end{array}$ & $\begin{array}{l}\text { a) } 3.0 \\
\text { b) } 5.0\end{array}$ & none & $\begin{array}{c}\text { Nd:YAG } \\
3,000 \mathrm{~W}(\mathrm{cw})\end{array}$ & butt joint & 200 & argon & 3.5 & 0.2 & $\begin{array}{c}\text { deep pen. } \\
\text { welding }\end{array}$ \\
\hline 7 & $\begin{array}{l}\text { a) stainless steel } 1.4301 \\
\text { b) stainless steel } 1.4301\end{array}$ & $\begin{array}{l}\text { a) } 2.0 \\
\text { b) } 3.0\end{array}$ & none & $\begin{array}{c}\mathrm{CO}_{2} \\
3,400 \mathrm{~W} \text { (pulse max.) }\end{array}$ & \multirow{2}{*}{ butt joint } & \multirow{2}{*}{200} & \multirow{2}{*}{ without } & \multirow{2}{*}{0.3} & 1.2 & $\begin{array}{c}\text { deep pen. } \\
\text { welding }\end{array}$ \\
\hline 8 & $\begin{array}{l}\text { a) brass } \\
\text { b) brass }\end{array}$ & $\begin{array}{l}\text { a) } 1.5 \\
\text { b) } 1.5\end{array}$ & none & $\begin{array}{c}\mathrm{CO}_{2} \\
1,700 \mathrm{~W} \text { (pulse max.) }\end{array}$ & & & & & 1.5 & $\begin{array}{c}\text { heat cond. } \\
\text { welding }\end{array}$ \\
\hline 9 & $\begin{array}{l}\text { a) electrical sheet } \\
\text { b) mild steel }\end{array}$ & $\begin{array}{l}\text { a) } 0.1 \\
\text { b) } 1.5\end{array}$ & $\begin{array}{l}\text { a: insulating } \\
\text { pol. coating }\end{array}$ & $\begin{array}{c}\mathrm{CO}_{2} \\
500 \mathrm{~W}(\mathrm{cw})\end{array}$ & \multirow{4}{*}{ lap joint } & \multirow{4}{*}{200} & \multirow{4}{*}{ nitrogen } & \multirow{4}{*}{1.0} & \multirow{4}{*}{0.15} & \multirow{4}{*}{$\begin{array}{l}\text { deep pen. } \\
\text { welding }\end{array}$} \\
\hline 10 & $\begin{array}{l}\text { a) baking tray } \\
\text { b) mild steel }\end{array}$ & $\begin{array}{l}\text { a) } 0.5 \\
\text { b) } 1.5 \\
\end{array}$ & $\begin{array}{l}\text { a: PTFE } \\
\text { coating }\end{array}$ & $\begin{array}{c}\mathrm{CO}_{2} \\
750 \mathrm{~W}(\mathrm{cw})\end{array}$ & & & & & & \\
\hline 11 & $\begin{array}{l}\text { a) mild steel } \\
\text { b) mild steel }\end{array}$ & \multirow{2}{*}{$\begin{array}{l}\text { a) } 1.5 \\
\text { b) } 1.5\end{array}$} & cold cleaner & \multirow{2}{*}{$\begin{array}{c}\mathrm{CO}_{2} \\
1,000 \mathrm{~W}(\mathrm{cw})\end{array}$} & & & & & & \\
\hline 12 & $\begin{array}{l}\text { a) mild steel } \\
\text { b) mild steel }\end{array}$ & & forming oil & & & & & & & \\
\hline
\end{tabular}

emission values have been related to relative costs for environmental measures (i.e. divided by the total production costs of the laser process, respectively).

\section{Results}

Gaseous compounds in the exhaust air including carbon monoxide and organic compounds have been found to be irrelevant with respect to the TLVs listed in [9] for all joining processes. In contrast, the total amount of aerosols and inorganic elements in the fume exceeded the TLVs in some cases. Table 2 gives an overview on the emission compounds which are relevant to air cleaning measures.

\subsection{Total amount of aerosol}

The lowest and highest emission rates and concentrations measured in the exhaust air (see Table 2) varied by more than one order of magnitude, respectively. In most cases, the concentrations stayed below the TLV for total aerosol emissions $\left(150 \mathrm{mg} / \mathrm{m}^{3}\right.$ for a mass flow $<200 \mathrm{~g} / \mathrm{h}$ [9] $)$. In two welding processes, however (highest laser power, global cabin capturing off, see Table 2), the aerosol concentration exceeded the TLV. Nevertheless, additional measures for waste-gas cleaning are not required for the processes regarded, if the global cabin capturing is running. In any case, the total aerosol mass flow was smaller than $200 \mathrm{~g} / \mathrm{h}$.

\subsection{Inorganic aerosol compounds}

Fig. 2a shows the inorganic composition of the exhaust fumes during laser soldering (Table 1 no. 1) and laser welding (Table 1 no. 5) of zinc-coated steel as determined by SEM-EDX.

During soldering (no. 1), the major inorganic emission compound in the exhaust air is zinc (93\%). The reason is that soldering is performed at temperatures far below the melting temperature of steel. However, zinc evaporates at soldering conditions due to the relatively low evaporation temperature $\left(907^{\circ} \mathrm{C}\right)$. Furthermore, the joint geometry (butt joint) may have an influence. In lap joint geometry, the area of zinc exposed to the laser beam would be much lower.

During laser welding of zinc-coated steel (see Fig. 2a, no. 5), the main component is also zinc (54\%). However, there is also a high amount of iron $(44 \%)$ in the fume. The reason is that much higher process temperatures are needed for welding than for soldering. Thus, a small part of the molten steel may evaporate, even at temperatures below the evaporation temperature, due to the vapour pressure of liquid steel. Taking into account that there is much more steel than zinc in the melt, it is not surprising that the welding fume contains such a high percentage of iron.

The emission of iron is uncritical as far as the TLV for total dust is not exceeded (200 g/h [9]). The same holds for zinc, because there is no specific TLV for zinc in [9]. However, it has to be noted that inorganic fumes may be critical in the air at the workplace due to the corresponding small TLV [11], which is $10 \mathrm{mg} / \mathrm{m}^{3}$, referred to the inhalable fraction, and $3 \mathrm{mg} / \mathrm{m}^{3}$, referred to the alveolar fraction. Thus, effective emission capturing is required, but special cleaning of the waste gas is not mandatory for the processes regarded in this work.

Fig. $2 \mathrm{~b}$ shows the inorganic elemental composition of dust samples for two welding processes of uncoated stainless steel. The composition is similar for both processes. The content of volatile elements is larger than in the base material. The major part of the emissions is still iron. However, there is a significant amount of critical elements listed in [9] $(\mathrm{Cr}, \mathrm{Mn}, \mathrm{Cu}, \mathrm{Ni})$. For these elements, the characteristic emission values have been calculated with respect to the following threshold values for the waste gas:

- $\sum \mathrm{dm} / \mathrm{dt}(\mathrm{Cr}, \mathrm{Cu}, \mathrm{Ni}, \mathrm{Mn})<5 \mathrm{~g} / \mathrm{h}$

- $\mathrm{dm} / \mathrm{dt}(\mathrm{Ni})<2.5 \mathrm{~g} / \mathrm{h}$ 
Cr amounts to $22-23 \%$ of the total aerosol emissions. In case of chromium, the amount of $\mathrm{Cr}(\mathrm{VI})$ is of special interest, as this species has a specific $\operatorname{TLV}(0.1 \mathrm{~g} / \mathrm{h})$, much lower than the TLV for total $\mathrm{Cr}(5 \mathrm{~g} / \mathrm{h})$. The reason is that $\mathrm{Cr}(\mathrm{VI})$ is considered as carcinogenic. The chemical analysis shows that the $\mathrm{Cr}(\mathrm{VI})$ concentration is uncritical for all joining processes regarded ( $3 \%$ of the TLV given in [9]).

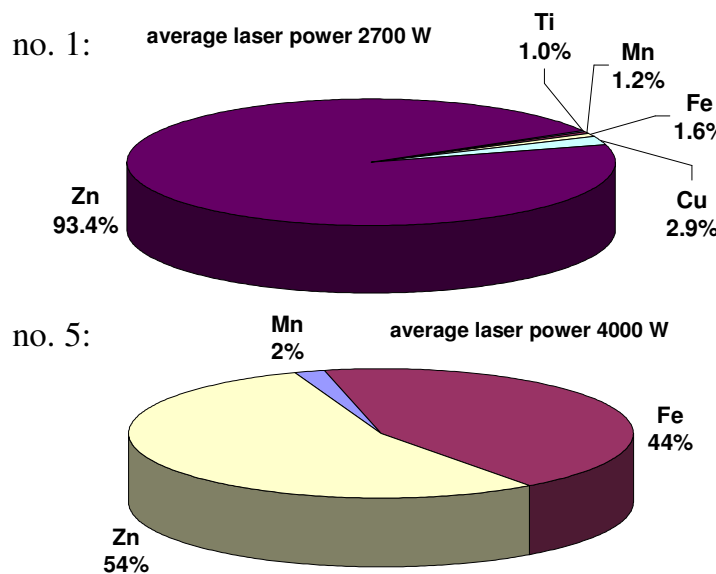

Fig. 2a Comparison of the exhaust fumes composition for soldering (no. 1) and welding (no. 5) processes

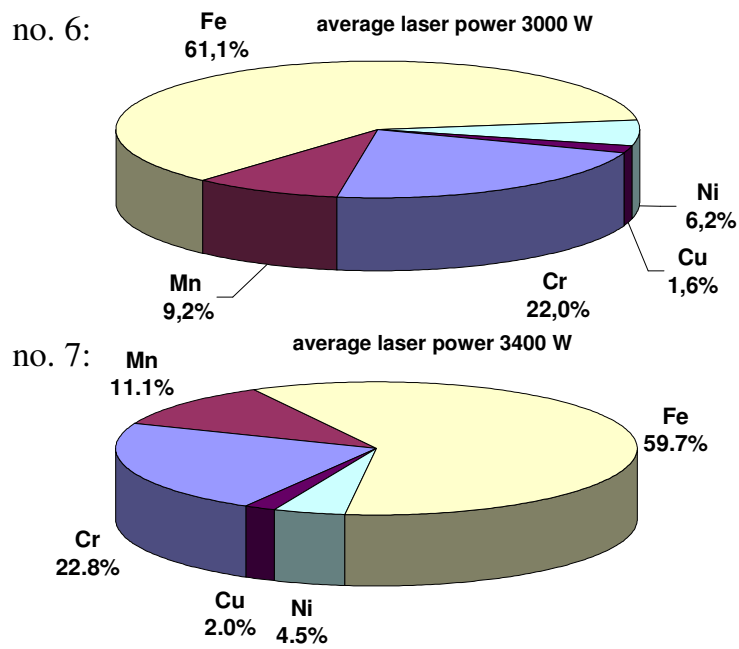

Fig. 2b Comparison of the exhaust fumes composition during welding of two stainless steel types (no. 6: 1.4404, no. 7: 1.4301).

The elemental analysis of the brass fume particles showed that the copper content in the particles is lower than in the base material. This can be explained by the higher volatility of zinc in comparison to copper. However, sedimentation was observed in the process zone which consists mainly of copper. The reason is that a part of the copper vaporises from the process zone and condenses to large particles before it enters the fume capturing device.

\subsection{Particle Size Distribution}

Fig. 3 exemplarily shows the particle size distribution for the laser welding process of PTFE-coated baking tray and mild steel. Obviously, the distribution function is bimodal which is typical for the laser processing of coated metals. The major part of the particulate emissions arises in the nanometer range, which is characteristic for all laser welding processes. Nanoparticles are assumed to have a much higher hazardous potential than usual dust particles which have been taken into account for the regulation of the threshold limit values according to [9]. The smaller the particles are, the higher is the total surface area of all particles. Several medical investigations show that the inflammatory response does not correlate to the particulate mass inhaled, but to the particulate surface dose of the lung above a certain threshold value [16-18]. From this point of view, laser processes have high hazardous potential, even if the aerosol concentrations are below the mass-specific threshold limit value for dust according to [9]. Compared to other welding processes, the specific surface of the particles emitted in laser processes is high, although the emitted mass flow is rather small [19].

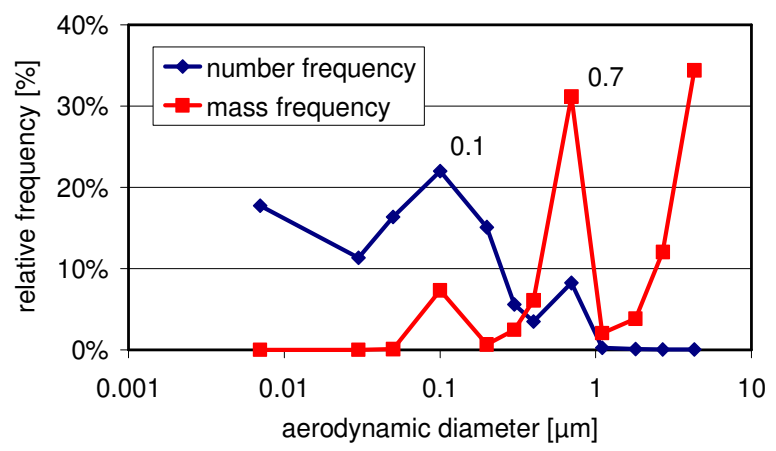

Fig. 3 Particle size distribution during laser welding of PTFE-coated baking tray and mild steel, no. 10 according to Table 1 (aerodynamic diameter: logarithmic scale).

On the other hand, the particle filtration efficiency is dependent on the particle size as well. According to [14], there is a relative minimum of the filtration efficiency at a particle diameter of about 0.2 to $0.3 \mu \mathrm{m}$. For larger particles, the filtration efficiency is increasing due to enhanced interception, inertial impaction or (for large particles) gravitational settling. Particles with diameters below $0.2 \mu \mathrm{m}$ show an increased tendency to be captured due to diffusion processes or electrostatic attraction. Thus, the danger of the nanoparticles emitted from the processes regarded in this work is relativized, because very small particles with diameters below $200 \mathrm{~nm}$ can be efficiently removed from the exhaust air using conventional filtering systems.

\subsection{Evaluation of results}

For all processes investigated, table 2 summarises the emission values which are relevant according to the German regulations for waste gas. As the content of volatile organic compounds and inorganic elements in the aerosol is always below the corresponding TLV according to [9], they are not listed in Table 2. Only the characteristic values for total aerosol emission are given.

Based on the results of emissions measurements in relation to the TLV values listed in [9], the laser processes can be classified into the following emission categories which require different measures of exhaust air cleaning:

Cat. 1: No filtering measures for the exhaust air are necessary, since all emissions comply with the TLVs.

Cat. 2: Particle filters according to the state-of-the-art are required if specific aerosol TLVs are exceeded.

Cat. 3: Filtration of gases according to the state-of-the-art is mandatory if TLVs for specific gaseous components are exceeded. 
Table 2 Results for aerosol emission rate and concentration measured in the exhaust air.

\begin{tabular}{|c|c|c|c|c|c|c|}
\hline $\begin{array}{c}\text { process no. } \\
\text { acc. to Table 1 }\end{array}$ & $\begin{array}{c}\text { process / } \\
\text { thickness [mm] }\end{array}$ & remarks & \begin{tabular}{|c|} 
laser power \\
[W]
\end{tabular} & $\begin{array}{c}\text { total aerosol } \\
\text { emission rate }[\mathrm{g} / \mathrm{h}] \\
(\mathrm{TLV}=200 \mathrm{~g} / \mathrm{h})\end{array}$ & $\begin{array}{l}\text { total aerosol conc. }\left[\mathrm{mg} / \mathrm{m}^{3}\right] \\
\left(\mathrm{TLV}=150 \mathrm{mg} / \mathrm{m}^{3} \mathrm{at}\right. \\
\text { emission rate }<200 \mathrm{~g} / \mathrm{h})\end{array}$ & $\begin{array}{l}\text { environmental } \\
\text { effort category }\end{array}$ \\
\hline \multirow{2}{*}{1} & \multirow{2}{*}{$\begin{array}{c}\text { soldering } \\
\text { thickness } 0.75\end{array}$} & cabin capturing off & \multirow{2}{*}{$2,700(\mathrm{cw})$} & 11.8 & 59 & \multirow{2}{*}{1} \\
\hline & & cabin capturing on & & 7.1 & 36 & \\
\hline \multirow{2}{*}{2} & \multirow{2}{*}{$\begin{array}{l}\text { heat cond welding } \\
\text { thickness } 0.7 \& 1.5\end{array}$} & cabin capturing off & \multirow{8}{*}{ 4,000 (cw) } & 23.6 & 118 & \multirow{2}{*}{1} \\
\hline & & cabin capturing on & & 20.0 & 100 & \\
\hline \multirow{2}{*}{3} & \multirow{2}{*}{$\begin{array}{l}\text { heat cond. welding } \\
\text { thickness } 1.5 \& 2.5\end{array}$} & cabin capturing off & & 33.2 & 166 & \multirow[b]{2}{*}{2} \\
\hline & & cabin capturing on & & 18.6 & 93 & \\
\hline \multirow{2}{*}{4} & \multirow{2}{*}{$\begin{array}{l}\text { heat cond. welding } \\
\text { thickn. } 0.7 \& 1.5 \& 1.5\end{array}$} & cabin capturing off & & 25.5 & 128 & \multirow{2}{*}{1} \\
\hline & & cabin capturing on & & 18.9 & 95 & \\
\hline \multirow{2}{*}{5} & \multirow{2}{*}{$\begin{array}{c}\text { heat cond. welding } \\
\text { thickn. } 0.7 \& 2.0 \& 1.5\end{array}$} & cabin capturing off & & 38.3 & 191 & \multirow{2}{*}{2} \\
\hline & & cabin capturing on & & 23.0 & 115 & \\
\hline 6 & deep pen. welding & circular seam & $3,000(\mathrm{cw})$ & 2.3 & 17 & 1 \\
\hline 7 & deep pen. welding & circular seam & $\begin{array}{c}3,400 \\
\text { (pulse max.) } \\
\end{array}$ & 1.4 & 6 & 1 \\
\hline 8 & heat cond. welding & longitudinal seam & $\begin{array}{c}1,700 \\
\text { (pulse max.) }\end{array}$ & 3.1 & 16 & 1 \\
\hline 9 & $\begin{array}{l}\text { deep pen. welding } \\
\text { thickness } 0.5 \& 1.5 \\
\end{array}$ & \multirow{4}{*}{ lap joint } & $500(\mathrm{cw})$ & 15.4 & 13 & 1 \\
\hline 10 & $\begin{array}{l}\text { deep pen. welding } \\
\text { thickness } 1.0 \& 1.5\end{array}$ & & $750(\mathrm{cw})$ & 9.6 & 8 & 1 \\
\hline 11 & \multirow{2}{*}{$\begin{array}{l}\text { deep pen. welding } \\
\text { thickness } 1.5 \& 1.5\end{array}$} & & \multirow{2}{*}{$1,000(\mathrm{cw})$} & 18.1 & 15 & 1 \\
\hline 12 & & & & 19.2 & 16 & 1 \\
\hline
\end{tabular}

Cat. 4: Additional measures are required, because e.g. acidic gases are emitted from the process zone, which must be neutralized according to the state of the art (usually not relevant to laser joining of metals).

It has to be noted that the hazardous potential of nanoparticles has not been taken into account in the above classification. It cannot be excluded that classification will change if the nanoparticulate character of process emissions is taken into account in future emission regulations.

\section{Calculation of costs for environmental measures in relation to total processing costs}

The total processing costs for the joining processes regarded in this work were calculated by the industrial partners (see acknowledgements). The cost values have been reported to the authors as total sums, whereas the calculation details have not been revealed. The costs caused by installation and operation of efficient capturing and filtering systems for the exhaust air (costs for environmental measures) have been calculated by the authors. Here, linear depreciation of filter investment costs over 5 years, costs for filter operation, consumption of electric energy, and costs for service actions have been considered, respectively.

The costs for environmental measures depend on the emission category into which the laser process is classified. They increase significantly from cat. 1 to cat. 4 . The calculated costs for environmental measures have been related to the total processing costs. Depending on this ratio, the laser processes investigated are classified into one of three cost ranges for exhaust air cleaning:

range $\mathrm{A}: \quad$ low costs $\leq 15 \%$

range $\mathrm{B}: \quad 15 \%<$ medium costs $<30 \%$

range $\mathrm{C}:$ high costs $\geq 30 \%$

These cost ranges have been defined in agreement with the industrial partners. As can be seen in Table 3, the costs for emission cleaning measures stay below $15 \%$ (cost range A) for all investigated material combinations and laser joining methods (emission categories 1-3).
Table 3 Costs for environmental measures related to the total manufacturing costs.

\begin{tabular}{|c|c|c|c|c|c|}
\hline no. & laser type & process & $\begin{array}{l}\text { total manufac- } \\
\text { turing } \\
\text { costs }\end{array}$ & $\begin{array}{l}\text { costs for } \\
\text { environm. } \\
\text { measures }\end{array}$ & $\begin{array}{l}\text { percent. } \\
\text { of total } \\
\text { costs }\end{array}$ \\
\hline 1 & $\begin{array}{c}\text { Nd:YAG } \\
\text { (cw) }\end{array}$ & soldering & $115 € / \mathrm{h}$ & $8.30 € / \mathrm{h}$ & $7.2 \%$ \\
\hline 2 & \multirow{3}{*}{$\begin{array}{c}\text { Nd:YAG } \\
\text { (cw) }\end{array}$} & \multirow{3}{*}{$\begin{array}{c}\text { heat cond. } \\
\text { welding }\end{array}$} & \multirow{3}{*}{$100 € / \mathrm{h}$} & \multirow{3}{*}{$8.30 € / \mathrm{h}$} & \multirow{3}{*}{$8.3 \%$} \\
\hline 3 & & & & & \\
\hline $\begin{array}{l}4 \\
5\end{array}$ & & & & & \\
\hline 6 & $\begin{array}{c}\text { Nd:YAG } \\
(\mathrm{cw})\end{array}$ & $\begin{array}{c}\text { deep pen. } \\
\text { welding }\end{array}$ & $90 € / \mathrm{h}$ & $4.70 € / \mathrm{h}$ & $5.0 \%$ \\
\hline 7 & $\mathrm{CO}_{2}$ (pulsed) & $\begin{array}{c}\text { deep pen. } \\
\text { welding }\end{array}$ & $85 € / \mathrm{h}$ & $4.70 € / \mathrm{h}$ & $5.5 \%$ \\
\hline 8 & $\mathrm{CO}_{2}$ (pulsed) & $\begin{array}{c}\text { heat cond. } \\
\text { welding }\end{array}$ & $60 € / \mathrm{h}$ & $4.70 € / \mathrm{h}$ & $7.8 \%$ \\
\hline 9 & $\mathrm{CO}_{2}(\mathrm{cw})$ & \multirow{3}{*}{$\begin{array}{l}\text { deep pen. } \\
\text { welding }\end{array}$} & \multirow{3}{*}{$75 € / \mathrm{h}$} & \multirow{3}{*}{$10.75 € / \mathrm{h}$} & \multirow{3}{*}{$14.3 \%$} \\
\hline 10 & $\mathrm{CO}_{2}(\mathrm{cw})$ & & & & \\
\hline $\begin{array}{l}11 \\
12\end{array}$ & $\mathrm{CO}_{2}(\mathrm{cw})$ & & & & \\
\hline
\end{tabular}

In the $4^{\text {th }}$ emission category, the costs for waste-gas cleaning are expected to exceed $15 \%$ of the total processing costs. This may happen if complex additional techniques have to be applied to meet the legal requirements.

The results are summarised in an interactive internet database which is made permanently available [10]. The database will be expanded in future using newly measured emission data.

\section{Conclusions and outlook}

In this work, the emission rates (mass per time) and concentrations (mass per exhaust air volume) during laser material processing, i.e. welding and soldering, were determined by characterizing emitted fumes. For the analyses, standard methods were used which are well known from literature. It was shown that the evaluated data can be correlated to costs for environmental measures (exhaust air cleaning) in relation to the total processing expenses. Thus, 
specific emission rates, given here as costs per time $[€ / \mathrm{h}]$, were calculated.

For a systematic classification of laser processes in the field of welding and soldering, four categories were defined according to the environmental efforts which are required to comply with the threshold limit values (TLVs) for particulate and gaseous emissions according to [9]. All laser joining processes which were investigated in this work can be allocated to the lower emission categories 1 to 3 . In addition, three environmental cost ranges were defined in order to rate the laser processes with regard to the costs for environmental measures.

The evaluation of the data which were collected in industrial environments shows that all processes investigated are related to costs for environmental measures below $15 \%$ of the total processing expenses. In many cases, waste gas cleaning even requires less than $8 \%$ of the total expenses. This clearly indicates that an adequate design of the environmental protection measures for laser joining processes can be done in an economic way.

An interactive laser-safety internet database with regard to laser process emissions, which has been available since several years [10], is revised so that information about the environmental cost ranges, which are related to the joining processes regarded in this work, can be extracted as well. In future, this database may be updated and extended by additional data deduced from further emission investigations of various laser processes.

The results obtained for the joining of metals show that the availability of characteristic emission values will be helpful with regard to economic planning and evaluation of industrial laser-based production processes. Consequently, it is planned for the near future to expand the investigations to the laser processing of polymers, taking into account theoretical modelling of the dependence on the process parameters. In this context, the formation of organic particulate and gaseous emissions, which typically have high hazardous potential, is of special relevance. An internet database, which provides characteristic emission values as well as cost-related information via environmental cost ranges, will help to reduce the number of necessary experimental investigations significantly. This is of particular importance e.g. for laser job shops, where comprehensive measurements of the emissions are not feasible due to the large variety of potential materials and processes.

\section{Acknowledgments and Appendixes}

Parts of this work have been funded by the Arbeitsgemeinschaft Industrieller Forschungsvereinigungen "Ottovon-Guericke" e.V. (AiF) in the frame of the AiF project no. $15.775 \mathrm{~N}$ and supervised by the Research Association on Welding and Allied Processes of the German Welding Society (DVS), which is gratefully acknowledged. The authors would like to give special thanks to the project partners Volkswagen AG, Nutech GmbH, and LMB Automation $\mathrm{GmbH}$ for the possibility to perform emission measurements in their facilities.

\section{References}

[1] Mayer, A.: Laser Technik Journal, 3/2009, pp. 8 - 9

[2] Lorenz, H.: Proc. Braunschweiger Symp. "Faszination Karosserie" (Braunschweig, 2003)
[3] Starlinger, A.; Leutenegger, S.: Proc. ICSAS $99-4^{\text {th }}$ Internat. Conf. on Light-Weight Steel and Aluminium Structures, Espoo, Finland (1999), pp. 465-472

[4] Barcikowski, S.; Hahn, A.; Ostendorf, A.: Proc. Internat. Laser Safety Conf. - ILSC, San Francisco, USA (2007), pp. 162-166

[5] Sattari, R.; Barcikowski, S.; Püster, T.; Ostendorf, A.; Haferkamp, H.: Proc. Internat. Laser Safety Conf. - ILSC, Marina del Rey, USA (2005), pp. 269-278

[6] Barcikowski, S.; Goede, M.; Haferkamp, H.: LaserOpto, 33 (2001), 4, pp. 68-71

[7] Bunte, J.; Barcikowski, S.; Püster, T.; Burmester, T.; Brose, M.; Ludwig, T.: The Ind. Laser User, 34 (2004), pp. 34-35

[8] Barcikowski, S.; Hahn, A.; Chichkov, B.N.: J. Laser Appl., 19 (2007), 2, pp. 65-73

[9] "Technische Anleitung zur Reinhaltung der Luft - TA Luft" (Technical Instructions on Air Quality Control), ed. by Verein Deutscher Ingenieure - VDI, $2^{\text {nd }}$ edition (Beuth, Berlin, 2006)

[10] Laser Zentrum Hannover e.V.: Laser Safety Database, ed. by Laser Zentrum Hannover e.V. - LZH, 1997, http://www.lzh.de/en/publications/laser_safety

[11] "Technical Rules for Hazardous Substances - Exposure Limit Values" (TRGS 900), ed. by Hazardous Substances Commission - AGS (Federal Ministry of Labour and Social Affairs, 2006, last adaptation 2010)

[12] v. Alvensleben, F.: „Abtragen mit Laserphotonen Arbeits- und Umweltschutz bei industriellen Abtragverfahren“, joint research project, Federal Ministry

of Education and Research, no. 13N7078/1, final report, ed. by Laser Zentrum Hannover e.V. - LZH (Hannover, 2000)

[13] "Particulate matter measurement - Dust measurement in flowing gases" - VDI 2066, VDI/DIN manual "Air Pollution Prevention", vol. 4: "Analysis and Measurement Methods". ed. by Verein Deutscher Ingenieure VDI (Beuth, Berlin, 2006)

[14] Hinds, W.C. (ed.): "Aerosol Technology - Properties, Behaviour, and Measurements of Airborne Particles", $2^{\text {nd }}$ edition (Wiley, New York, 1999), pp. 191-200

[15] Barcikowski, S.; Walter, J.; Hahn, A.; Koch, J.; Haloui, H.; Herrmann, T.; Gatti, A.: JLMN - J. Laser Micro / Nanoeng., 4 (2009), 3, pp. 159-164

[16] Oberdörster, G.; Oberdörster, E.; Oberdörster, J.: Nanotoxicology: Environ. Health Perspect., 113 (2005), 7, pp. 823-839

[17] Stoeger, T.; Reinhard, C.; Takenaka, S.; Schroeppel, A.; Karg, E.; Ritter, B.; Heyder, J.; Schulz, H.: Environ. Health Persp., 114 (2006), 3, pp. 328-333

[18] Faux, S.P.; Tran, C.L.; Miller, B.G.; Jones, A.D.; Montellier, C.; Donaldson, K.: "In vitro determinants of particulate toxicity: The dosemetric for poorly soluble dusts". Health and Safety Executive, Research Report 154 (HSE Books, Sudbury/Suffolk, 2003)

[19] Pohlmann, G.; Koch, W.; Holzinger, K.; Dilthey, U.: „Vergleichende Untersuchungen bezüglich der Charakterisierung der ultrafeinen Partikel in Schweißrauchen beim Schweißen und bei verwandten Verfahren“, final report, ed. by Vereinigung der Metall-Berufsgenossenschaften - VMBG (Düsseldorf, 2008) 
(Recieved: June 07, 2010, Accepted: July 05, 2011) 